\title{
PENGARUH KARATERISTIK PERUSAHAAN, STRUKTUR KEPEMILIKAN, DAN GOOD CORPORATE GOVERNANCE TERHADAP LUAS PENGUNGKAPAN TRIPLE BOTTOM 'LINE PADA PERUSAHAAN LQ45 YANG TERDAFTAR DI BEI TAHUN 2014-2016
}

\author{
Yunina $^{1}$, Nur Fadillah ${ }^{2}$ \\ ${ }^{1,2}$ Prodi Akuntansi Fakultas Ekonomi dan Bisnis Universitas Malikussaleh Lhokseumawe \\ 1 yunina@unimal.ac.id, ${ }^{2}$ nf.fadillah001@gmail.com
}

\begin{abstract}
This study aimed to know the influence of company characteristics, ownership structure and good corporate governance on the disclosure of the Triple Bottom Line. The samples of this research were taken using purposive sampling based on certain criteria and the samples were 23 companies from a population of 45 companies. This study used multiple regression analysis with hypothesis testing using SPSS 17 for Windows. The results showed that leverage, Profitability, and foreign ownership did not have a significant effect on the level of triple bottom line disclosure, institutional ownership, ownership, board size and audit committee size did not significantly affect the triple bottom line disclosure level. While liquidity, industry type and company age significantly influenced the triple bottom line disclosure level. For the next researcher, it is better to use other variables and the number of years extended to be more relevant.
\end{abstract}

Keywords: Triple Bottom Line, Company Characteristics, Ownership Structur Good Corporate Governance.

\section{PENDAHULUAN}

Salah satu informasi yang perlu diungkapkan adalah tanggung jawab sosial perusahaan. Sumber daya ekonomi perusahaan berhubungan langsung dengan dimensi sosial dan lingkungan, sehingga peranannya sangat signifikan dalam menunjang ekonomi perusahaan. Dengan konsep pembangunan yang berkelanjutan, perusahaan tidak lagi dihadapkan pada tanggung jawab yang berpijak pada single bottom line (SBL), yaitu nilai perusahaan (corporate value) yang direfleksikan dalam kondisi ekonomi (financial) saja . Tetapi lebih berpijak pada triple bottom line (TBL) yaitu ekonomi, sosial dan lingkungan (Sandra, 2011).

Banyak perusahaan di Indonesia yang sudah mengungkapkan tanggung jawab sosial, tetapi masih dalam tingkat sukarela. Pengungkapan tanggungjawab sosial perusahaan disusun dengan menggunakan item yang berfokus pada konsep Corporate Social Responsibility. Padahal sebenarnya Corporate Social Responsibility itu berasal dari pemikiran konsep triple bottom line yang disampaikan oleh John Elkington (1997) yang menyatakan bahwa perusahaan harus melakukan konsep ini agar perusahaan dapat sustainable.

Gambaran fenomena kegagalan CSR yang muncul di Indonesia antara lain kasus PT Newmont Minahasa Raya, kasus Lumpur panas Sidoarjo, kasus perusahaan tambang minyak dan gas bumi, Unicoal (perusahaan Amerika Serikat), kasus PT Kelian Equatorial Mining pada komunitas Dayak, kasus suku Dayak dengan perusahaan tambang emas milik Australia (Aurora Gold), kasus pencemaran air raksa yang mengancam kehidupan 1,8 juta jiwa penduduk Kalimantan Tengah yang merupakan kasus suku Dayak dengan Minamata, kasus kerusakan lingkungan di lokasi penambangan timah inkonvensional di pantai Pulau Bangka-Belitung, dan konflik antara PT Freeport Indonesia dengan rakyat Papua. Namun demikian banyak juga perusahaan-perusahaan di Indonesia yang sukses dalam menjalankan CSR. Fenomena keberhasilan CSR antara lain dilakukan oleh PT. Djarum dengan program beasiswa bagi para mahasiswa berprestasi. PT. Indocement Tunggal Prakasa, Tbk. adalah salah satu contoh perusahaan yang sangat peduli pada kelestarian lingkungan hidup melakukan kegiatan Program Clean Development Mechanism (CDM). Program Mitra Produksi Sampoerna (MPS) merupakan program kemitraan yang dilakukan dengan perusahaan kecil dan menengah, koperasi, dan pondok pesantren untuk menjadi mitra produksi perusahaan (Anatan, 2010 dan Tjahyono, 2011).

Perusahaan membutuhkan biaya dalam rangka memberikan informasi tentang pertanggung jawaban sosial, sehingga laba yang dilaporkan pun menjadi lebih rendah. Oleh karena itu, manajemen perusahaan sebagai wujud tanggung jawabnya kepada pihak yang memberi wewenang (prinsipal) berusaha memenuhi kepentingannya, yaitu dalam pengungkapan informasi pertanggungjawaban sosial perusahaan. Banyak faktor yang mempengaruhi pengungkapan triple bottom line yaitu karakteristik perusahaan, struktur kepemilikan, dan good corporate governance. 


\section{LANDASAN TEORI}

\section{Triple Botoom Line}

Dalam era globalisasi perusahaan tidak hanya mementingkan aspek ekonomi saja, tetapi harus memperhatikan kepentingan sosial dan lingkungan. Seperti penelitian Sandra (2011) menyatakan bahwa perusahaan yang berkelanjutan bukan hanya mengejar keuntungan financial, bukan hanya peningkatan nilai pemegang saham. Namun yang paling baik adalah dicapai melalui kerangka kerja yang luas di bidang ekonomi, sosial, lingkungan dan nilai-nilai etika serta tujuan bersama yang melibatkan interaksi antara perusahaan dan berbagai pemangku kepentingan. Selanjutnya, konsep ini dikembangkan seperti penelitian $\mathrm{Zu}$ (2009) dalam Sandra (2011) mengungkapkan tentang teori triple bottom line dengan tiga aspek utama yaitu, ekonomis, sosial dan lingkungan.

Triple bottom line menangkap spektrum yang lebih luas dari nilai-nilai dan kriteria untuk mengukur kesuksesan organisasi yaitu ekonomi, lingkungan dan sosial. Hal ini berarti memperluas kerangka kerja pelaporan sederhana untuk memperhitungkan kinerja sosial dan lingkungan disamping kinerja keuangan. Ini juga menangkap esensi pembangunan berkelanjutan (sustainability development) dengan mengukur dampak ketiga aspek tersebut dari kegiatan operasi perusahaan.

\section{Karakteristik Perusahaan}

Karakteristik perusahaan dapat menjelaskan variasi luas pengungkapan sukarela dalam laporan tahunan, karakteristik perusahaan merupakan prediktor kualitas pengungkapan. Setiap perusahaan memiliki karakteristik yang berbeda antara entitas yang satu dengan yang lain. Dalam penelitian ini karekteristik perusahaan yang mempengaruhi luas pengungkapan Triple bottom mengacu pada penelitan yang dilakukan Nugroho dan Purwanto (2013) yaitu leverage, Profitabilitas, likuiditas, jenis Industri dan umur perusahaan.

\section{Struktur Kepemilikan}

Para peneliti berpendapat bahwa struktur kepemilikan perusahaan memiliki pengaruh terhadap perusahaan. Tujuan perusahaan sangat ditentukan oleh struktur kepemilikan, motivasi pemilik, dan kreditur corporate governance dalam proses insentif yang membentuk motivasi manajer. Pemilik akan berusaha membuat berbagai strategi untuk mencapai tujuan perusahaan, setelah stretegi ditentukan maka langkah selanjutnya akan mengimplementasi strategi dan mengalokasikan sumber daya yang dimiliki perusahaan untuk mencapai tujuan perusahaan. Semua tahapan tersebut tidak terlepas dari peran pemilik dapat dikatakan bahwa peran pemilik sangat penting dalam menentukan keberlangsungan persahaan.
Dalam hal ini kepemilikan dibedakan menjadi 3 yaitu kepemilikan asing, kepemilikan manajerial, dan kepemilikan institusional.

\section{Good Corporate Governance}

Dalam penerapan Good Corporate Governance (GCG), tidak terlepas dari budaya organisasi yang berlaku di dalam organisasi itu sendiri. Budaya menurut Schein (2010:5) adalah fenomena dinamis dalam kondisi "disini dan saat ini” dan sebuah latar belakang sturktur paksaan yang berpengaruh pada kelompok melalui beberapa cara. Budaya sendiri secara terus-menerus diterapkan dan tercipta oleh interaksi yang dilakukan kelompok dengan terbentuk oleh perilaku kelompok itu sendiri. Greertz (dalam Driskill \& Brendton 2010: 8) berpendapat pada budaya organisasi terdiri dari jaringan yang signifikan yang terus dipintal oleh organisasi itu sendiri, serta dibangun melalui adanya interaksi.

\section{Kerangka Konseptual}

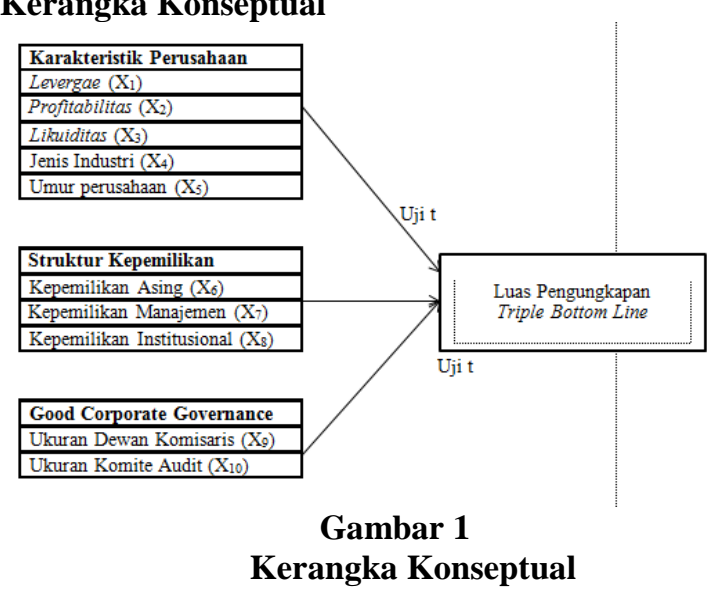

Perumusan Hipotesis

H1 : Leverage berpengaruh Terhadap Luas Pengungkapan triple bottom line

H2 : Profitabilitas Berpengaruh terhadap luas pengungkapan triple bottom line

H3 : Likuiditas berpengaruh terhadap luas pengungkapan triple bottom line

H4 : Jenis industri berpengaruh terhadap luas pengungkapan triple bottom line H5: Umur perusahaan berpengaruh terhadap luas pengungkapan triple bottom line

H6 :Kepemilikan asing berpengaruh terhadap luas pengungkapan triple bottom line

H7 : Kepemilikan manajemen berpengaruh terhadap luas pengungkapan triple bottom line

H8: Kepemilikan institusional berpengaruh terhadap luas pengungkapan triple bottom line. 1

H9 : Ukuran dewan komisaris berpengaruh terhadap luas pengungkapan triple bottom line. 
H10 : Ukuran komite audit berpengaruh terhadap luas pengungkapan triple bottom line.

\section{METODE PENELITIAN}

\section{Populai Dan Sampel}

Populasi yang digunakan adalah perusahaan LQ45 yang terdaftar di Bursa Efek Indonesia (BEI) tahun 2014 - 2016 yaitu sebanyak 45 perusahaan. Sedangkan sampel dalam penelitian ini berjumlah 23 dan 3 tahun pengamatan dengan metode pengambilan sampel menggunakan purposive sampling. Kriteria populasi yang ditetapkan dalam penelitian ini adalah sebagai berikut:

1. Perusahaan yang konsisten berada pada LQ45 tahun 2014-2016

2. Perusahaan LQ45 yang menerbitkan laporan keuangan dari tahun 2014-2016.

3. Perusahaan yang melaporkan laporan keuangan dalam satuan Rupiah

\section{Jenis Dan Sumber Data}

Jenis data yang diambil peneliti dalam penelitian ini berdasarkan dengan kelompok jenis data yaitu: Jika dilihat berdasarkan cara perolehan data ini merupakan data sekunder dikarenakan penelitian ini menggunakan data dari laporan keuangan dari perusahaan yang bersangkutan.

\section{Operasional Variabel}

Tabel 1

Tabel Definisi Operasional Variabel

\begin{tabular}{|c|c|c|c|}
\hline Variabel & Definisi & Indikator & Skala \\
\hline $\begin{array}{c}\text { Luas } \\
\text { Pengungk } \\
\text { apan } \\
\text { Triple } \\
\text { Bottom } \\
\text { Line (Y) }\end{array}$ & $\begin{array}{l}\text { Aspek ekonomi } \\
\text { yang tidak } \\
\text { hanya berfokus } \\
\text { pada masalah } \\
\text { finansial } \\
\text { namum juga } \\
\text { harus } \\
\text { memperhatikan } \\
\text { aspek sosial } \\
\text { dan lingkungan } \\
\text { sekitarnya. }\end{array}$ & $\begin{array}{l}\text { TBLD = } \\
\text { Total Item } \\
\text { yang } \\
\text { diungkapka } \\
\text { n/total item } \\
\text { seluruhnya } \\
\text { x } 100 \%\end{array}$ & Rasio \\
\hline $\begin{array}{l}\text { Leverage } \\
\left(\mathrm{X}_{1}\right)\end{array}$ & $\begin{array}{l}\text { leverage juga } \\
\text { memberikan } \\
\text { gambaran } \\
\text { tentang } \\
\text { mengenai } \\
\text { struktur } \\
\text { modal yang } \\
\text { dimiliki } \\
\text { perusahaan, } \\
\text { sehingga } \\
\text { dapat dilihat } \\
\text { tingkat resiko } \\
\text { tak }\end{array}$ & $\begin{array}{c}\text { Total } \\
\text { Hutang } \\
\text { Ekuitas } \\
\text { Pemegang } \\
\text { Saham }\end{array}$ & Rasio \\
\hline
\end{tabular}

\begin{tabular}{|c|c|c|c|}
\hline & $\begin{array}{l}\text { tertagihnya } \\
\text { suatu utang. }\end{array}$ & & \\
\hline \multirow[t]{2}{*}{$\begin{array}{l}\text { Profitabili } \\
\operatorname{tas}\left(\mathrm{x}_{2}\right)\end{array}$} & \multirow{2}{*}{$\begin{array}{l}\text { kemampuan } \\
\text { perusahaan } \\
\text { dalam } \\
\text { menghasilkan } \\
\text { laba } \\
\text { pada } \\
\text { operasinya }\end{array}$} & Laba & Rasio \\
\hline & & $\begin{array}{c}\text { Setelah } \\
\text { Pajak } \\
\text { Total Aset }\end{array}$ & \\
\hline \multirow[t]{2}{*}{$\begin{array}{l}\text { Likuiditas } \\
\left(\mathrm{X}_{3}\right)\end{array}$} & \multirow{2}{*}{$\begin{array}{l}\text { kemampuan } \\
\text { perusahaan } \\
\text { dalam } \\
\text { melunasi } \\
\text { tanggung } \\
\text { jawab } \\
\text { kewajibankew } \\
\text { ajiban } \\
\text { jangka } \\
\text { pendeknya }\end{array}$} & Aktiva & Rasio \\
\hline & & $\begin{array}{l}\text { Lancar } \\
\text { Hutang } \\
\text { Lancar }\end{array}$ & \\
\hline $\begin{array}{l}\text { Jenis } \\
\text { Industri } \\
\left(\mathrm{X}_{4}\right)\end{array}$ & $\begin{array}{l}\text { jenis } \\
\text { perusahaan } \\
\text { yang } \\
\text { berdasarkan } \\
\text { hubungan } \\
\text { perusahaan } \\
\text { dengan } \\
\text { hubungannya } \\
\text { dengan } \\
\text { masyarakat. }\end{array}$ & $\begin{array}{l}\text { Low profile } \\
(0), \\
\text { High profile } \\
\text { (1) }\end{array}$ & $\begin{array}{c}\text { Nomi } \\
\text { nal }\end{array}$ \\
\hline $\begin{array}{l}\text { Umur } \\
\text { Perusahaa } \\
\mathrm{n}\left(\mathrm{X}_{5}\right)\end{array}$ & $\begin{array}{l}\text { Umur } \\
\text { perusahaan } \\
\text { dapat } \\
\text { menunjukkan } \\
\mathrm{n} \text { bahwa } \\
\text { perusahaan } \\
\text { tetap eksis } \\
\text { dan mampu } \\
\text { bersaing }\end{array}$ & $\begin{array}{l}\text { Umur } \\
\text { perusahaan } \\
=\text { Tahun } \\
\text { ke-n (tahun } \\
\text { first issue di } \\
\text { BEI) }\end{array}$ & Rasio \\
\hline $\begin{array}{l}\text { Kepemili } \\
\text { kan Asing } \\
\left(\mathrm{X}_{6}\right)\end{array}$ & $\begin{array}{l}\text { Kepemilikan } \\
\text { saham } \\
\text { perusahaan } \\
\text { oleh pihak } \\
\text { asing }\end{array}$ & $\begin{array}{l}\text { Persentase } \\
\text { kepemilikan } \\
\text { asing }(\%)\end{array}$ & Rasio \\
\hline $\begin{array}{l}\text { Kepemili } \\
\text { kan } \\
\text { Manajem } \\
\text { en }\left(X_{7}\right)\end{array}$ & $\begin{array}{l}\text { Kepemilikan } \\
\text { saham } \\
\text { perusahaan } \\
\text { oleh pihak } \\
\text { manajemen } \\
\text { perusahaan } \\
\text { itu sendiri }\end{array}$ & $\begin{array}{l}\text { Persentase } \\
\text { kepemilikan } \\
\text { saham } \\
\text { manajemen } \\
(\%) .\end{array}$ & Rasio \\
\hline $\begin{array}{l}\text { Kepemili } \\
\text { kan } \\
\text { Institusio } \\
\text { nal }\left(\mathrm{X}_{8}\right)\end{array}$ & $\begin{array}{l}\text { Kepemilikan } \\
\text { saham } \\
\text { perusahaan } \\
\text { oleh institusi } \\
\text { lainnya }\end{array}$ & $\begin{array}{l}\text { Persentase } \\
\text { kepemilikan } \\
\text { saham } \\
\text { institusoinal } \\
(\%)\end{array}$ & Rasio \\
\hline
\end{tabular}




\begin{tabular}{|l|l|l|l|}
\hline Ukuran & Banyaknya & Jumlah & Rasio \\
Dewan & jumlah dewan & dewan & \\
Komisaris & komisaris & komisaris & \\
$\left(\mathrm{X}_{9}\right)$ & perusahaan & & \\
\hline Ukuran & Banyaknya & Jumlah & Rasio \\
Komite & jumlah & komite audit & \\
Audit & komite audit & & \\
$\left(\mathrm{X}_{10}\right)$ & diperusahaan & & \\
\hline
\end{tabular}

Uji Regresi Linier Bergada

Adapun formulasi persamaan regresi berganda sebagai berikut:

$Y=a+b_{1} X_{1}+b_{2} X_{2}+b_{3} X_{3}+b_{4} X_{4}+b_{5} X_{5}+b_{6} X_{6}+$ $\mathbf{b}_{7} \mathbf{X}_{7}+\mathbf{b}_{\mathbf{8}} \mathbf{X}_{\mathbf{8}}+\mathbf{b}_{\mathbf{9}} \mathbf{X}_{\mathbf{9}}+\mathbf{b}_{10} \mathbf{X}_{10}+\mathbf{e}$ Keterangan :

$\begin{array}{ll}\mathrm{Y} & \text { : Triple Bottom Line } \\ \mathrm{a} & \text { : Konstanta } \\ \mathrm{b} & \text { : Koefisien Regresi } \\ \mathrm{X}_{1} & \text { : Leverage } \\ \mathrm{X}_{2} & \text { : Provitabilitas } \\ \mathrm{X}_{3} & \text { : Likuiditas } \\ \mathrm{X}_{4} & \text { : Jenis Industri } \\ \mathrm{X}_{5} & \text { : Umur Perusahaan } \\ \mathrm{X}_{6} & \text { : Kepemilikan Asing } \\ \mathrm{X}_{7} & \text { : Kepemilikan Manajemen } \\ \mathrm{X}_{8} & \text { : Kepemilikan Institusional } \\ \mathrm{X}_{9} & \text { : Ukuran Dewan Komisaris } \\ \mathrm{X}_{10} & \text { : Ukuran Komite Audit } \\ \mathrm{e} & \text { : Error term }\end{array}$

\section{HASIL DAN PEMBAHASAN}

\section{Uji Asumsi Klasik}

\section{a. Uji Normalitas}

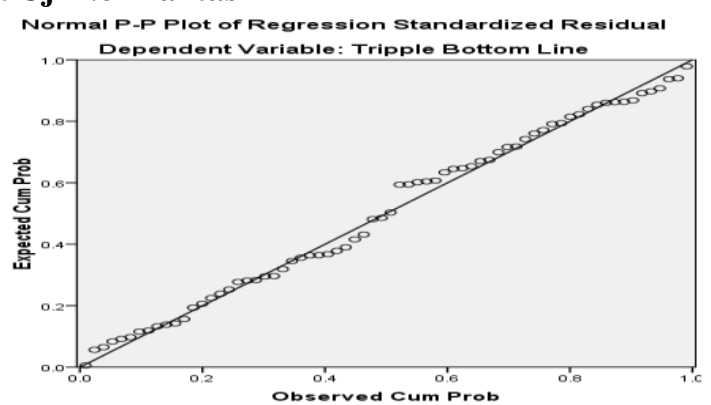

Gambar 2

Observed Cum Prob

Berdasarkan hasil output grafik normal probability plot menunjukkan penyebaran titik berada disekitar garis diagonal, oleh karena itu dapat dikatakan bahwa model regresi berdistribusi normal.

\section{b. Uji Autokorelasi}

Tabel 2

Model Summary ${ }^{b}$

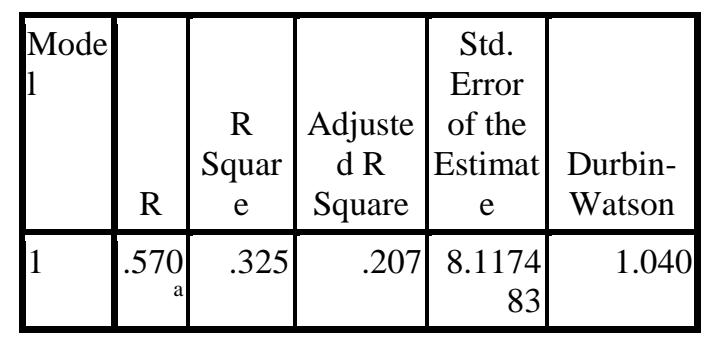

a. Predictors: (Constant), Ukuran Komite Audit, Kepemilikan Manajemen, Kepemilikan Institusional, Likuiditas, Jenis Industri, ROA, Kepemilikan Asing, Umur Perusahaan, Ukuran Komisaris, Leverage

$$
\begin{aligned}
& \text { b. Dependent Variable: Tripple } \\
& \text { Bottom Line }
\end{aligned}
$$

Berdasarkan hasil perhitungan tabel diatas nilai DW sebesar 1,040 dengan jumlah $\mathrm{k}$ (variabel independen) sebanyak 10 dan jumlah sampel sebanyak 68. Dalam tabel Durbin Warson menunjukkan nilai dL (batas bawah) $=1,289$ dan $\mathrm{dU}$ (batas atas) $=1,954$, sehingga nilai D-W 1,040 lebih besar dari 0 dan kurang dari dU. Sehingga dapat disimpulkan bahwa tidak ada autokorelasi dalam model regresi.

\section{c. Uji Multikolinieritas}

dapat kita lihat hasil VIF untuk reputasi underwriter sebesar 1,106 sedangkan untuk persentase saham yang ditawarkan ke publik sebesar 1,050 dan penggunaan dana IPO untuk investasi sebesar 1,152. Karena nilai VIF kurang dari 10 dan tolerance value diatas 0,10 maka dapat disimpulkan bahwa pada model regresi tidak di temukan masalah Multikolinearitas.

\section{d. Uji Heteroskedatisitas}

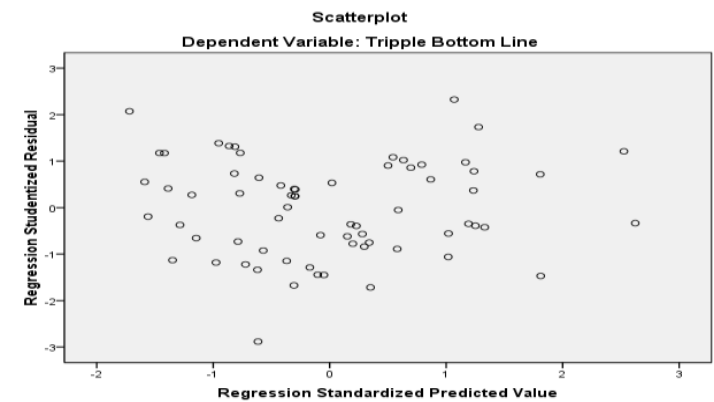

Gambar 3

Regression Standardized Predicted Value

Berdasarkan hasil uji heteroskedastisitas pada gambar Grafik scatter plot menunjukkan bahwa titik-titik menyebar secara acak serta tersebar baik di atas maupun di bawah angka 0 pada sumbu Y. Hal ini dapat disimpulkan bahwa tidak terjadi heteroskedastisitas pada model regreso, sehingga model regresi layak dipakai untuk memprediksi tingkat Underpricing berdasarkan masukan variabel independen reputasi 
underwriter, persentase saham yang ditawarkan ke publik dan penggunaan dana IPO untuk investasi.

\section{Uji Linier Berganda}

Tabel 3

Coefficients $^{\mathrm{a}}$

\begin{tabular}{|c|c|c|c|c|c|}
\hline \multirow[t]{2}{*}{ Model } & \multicolumn{2}{|c|}{$\begin{array}{c}\text { Unstandardiz } \\
\text { ed } \\
\text { Coefficients }\end{array}$} & \multirow{2}{*}{\begin{tabular}{|c|}
$\begin{array}{c}\text { Standardize } \\
\mathrm{d} \\
\text { Coefficient } \\
\mathrm{s}\end{array}$ \\
\\
Beta
\end{tabular}} & \multirow[b]{2}{*}{$\mathrm{t}$} & \multirow[b]{2}{*}{ Sig } \\
\hline & B & $\begin{array}{l}\text { Std. } \\
\text { Error }\end{array}$ & & & \\
\hline 1 (Constant) & $\begin{array}{r}63.81 \\
4\end{array}$ & 6.887 & & $\begin{array}{r}9.26 \\
6\end{array}$ & $\begin{array}{r}.00 \\
0\end{array}$ \\
\hline Leverage & 1.782 & .909 & .284 & $\begin{array}{r}1.96 \\
1\end{array}$ & $\begin{array}{r}.05 \\
5\end{array}$ \\
\hline $\begin{array}{l}\text { Profitabilit } \\
\text { as }\end{array}$ & -3.491 & 2.055 & -.201 & 1.69 & $\begin{array}{r}.09 \\
5\end{array}$ \\
\hline Likuiditas & -1.603 & .593 & -.373 & $2.70^{-}$ & $\begin{array}{r}.00 \\
9\end{array}$ \\
\hline $\begin{array}{l}\text { Jenis } \\
\text { Industri }\end{array}$ & 5.694 & 2.352 & .314 & $\begin{array}{r}2.42 \\
1\end{array}$ & $\begin{array}{r}.01 \\
9\end{array}$ \\
\hline $\begin{array}{l}\text { Umur } \\
\text { Perusahaa } \\
\mathrm{n}\end{array}$ & -.550 & .162 & -.458 & $\begin{array}{r}- \\
3.39 \\
7\end{array}$ & $\begin{array}{r}.00 \\
1\end{array}$ \\
\hline $\begin{array}{l}\text { Kepemilik } \\
\text { an Asing }\end{array}$ & .000 & .002 & -.049 & $\begin{array}{r}- \\
.397\end{array}$ & $\begin{array}{r}.69 \\
3\end{array}$ \\
\hline $\begin{array}{l}\text { Kepemilik } \\
\text { an } \\
\text { Institusion } \\
\text { al }\end{array}$ & -2.164 & 5.374 & -.048 & $\begin{array}{r}- \\
.403\end{array}$ & $\begin{array}{r}.68 \\
9\end{array}$ \\
\hline $\begin{array}{l}\text { Kepemilik } \\
\text { an } \\
\text { Manajeme } \\
\mathrm{n}\end{array}$ & -.066 & .041 & -.201 & $\begin{array}{r}- \\
1.60 \\
3\end{array}$ & $\begin{array}{r}.11 \\
5\end{array}$ \\
\hline $\begin{array}{l}\text { Ukuran } \\
\text { Komisaris }\end{array}$ & .290 & .676 & .060 & .428 & $\begin{array}{r}.67 \\
0\end{array}$ \\
\hline $\begin{array}{l}\text { Ukuran } \\
\text { Komite } \\
\text { Audit }\end{array}$ & -2.470 & 1.457 & -.231 & $\begin{array}{r}- \\
1.69 \\
5\end{array}$ & $\begin{array}{r}.09 \\
6\end{array}$ \\
\hline
\end{tabular}

a. Dependent Variable: Tripple Bottom Line

Berdasarkan nilai konstanta dan koefisien regresi tersebut, maka hubungan antara variabelvariabel independen dengan variabel dependen dalam model regrsi dapat dirumuskan sebagai berikut :

$$
\begin{gathered}
\mathrm{Y}=63,814+0,284 \mathrm{X}_{1}-0,201 \mathrm{X}_{2}-0,373 \mathrm{X}_{3} \\
+0,314 \mathrm{X}_{4}-0,458 \mathrm{X}_{5}-0,049 \mathrm{X}_{6}-0,048 \mathrm{X}_{7}- \\
0,201 \mathrm{X}_{8}+0,060 \mathrm{X}_{9}-0,231 \mathrm{X}_{10}+\mathrm{e}
\end{gathered}
$$

Dari persamaan regresi diatas dapat dijadikan sebagai berikut :
1. Nilai konstanta (a) adalah 63,814 , dapat diartikan jika leverage, ROA, Likuiditas, Jenis industri, umur perusahaan, kepemilikan asing, kepemilikan institusional, kepemilikan manajemen, ukuran komisaris dan ukuran komite audit nilainya 0 (nol), maka tingkat pengungkapan triple bottom line adalah sebesar 63,814 satuan.

2. Nilai koofisien regresi variabel Leverage $\left(b_{1}\right)$ bernilai positif, yaitu 0,284 , maka dapat diartikan bahwa setiap peningkatan leverage sebesar $1 \%$ maka akan menaikkan tingkat pengungkapan triple bottom line sebesar $28,4 \%$ dengan asumsi variabel independen lainnya tetap.

3. Nilai koofisien regresi variabel Profitabilitas (ROA) $\left(b_{2}\right)$ bernilai negatif yaitu sebesar -0,201, maka dapat diartikan bahwa setiap peningkatan ROA sebesar $1 \%$ maka akan menurunkan tingkat pengungkapan triple bottom line sebesar $20,1 \%$ dengan asumsi variabel independen lainnya tetap.

4. Nilai koofisien regresi variabel Likuiditas $\left(b_{3}\right)$ bernilai negatif yaitu sebesar $-0,373$, maka dapat diartikan bahwa setiap peningkatan likuiditas sebesar $1 \%$ maka akan menurunkan tingkat pengungkapan triple bottom line sebesar 37,3\% dengan asumsi variabel independen lainnya tetap.

5. Nilai koofisien regresi variabel jenis industri $\left(b_{4}\right)$ bernilai positif yaitu sebesar 0,314, maka dapat diartikan bahwa setiap peningkatan persentse saham yang ditawarkan ke publik sebesar 1\% maka akan meningkatkan tingkat triple bottom line sebesar 0,314 dengan asumsi variabel independen lainnya tetap.

6. Nilai koofisien regresi variabel umur perusahaan $\left(b_{5}\right)$ bernilai negatif yaitu sebesar -0,458, maka dapat diartikan bahwa setiap penurunan umur perusahaan sebesar $1 \%$ maka akan meningkatkan tingkat pengungkapan triple bottom line sebesar $45,8 \%$ dengan asumsi variabel independen lainnya tetap.

7. Nilai koofisien regresi variabel kepemilikan asing $\left(b_{6}\right)$ bernilai negatif yaitu sebesar -0,049, maka dapat diartikan bahwa setiap penurunan kepemilikan asing sebesar $1 \%$ maka akan meningkatkan tingkat triple bottom line sebesar 4,9\% dengan asumsi variabel independen lainnya tetap.

8. Nilai koofisien regresi variabel kepemilikan institusional $\left(b_{7}\right)$ bernilai negatif yaitu sebesar -0,048, maka dapat diartikan bahwa setiap penurunan kepemilikan institusi sebesar $1 \%$ maka 
akan meningkatkan tingkat pengun gkapan triple bottom line sebesar 4,8\% dengan asumsi variabel independen lainnya tetap.

9. Nilai koofisien regresi variabel kepemilikan manajemen $\left(b_{8}\right)$ bernilai negatif yaitu sebesar -0,201, maka dapat diartikan bahwa setiap penurunan kepemilikan manajemen sebesar $1 \%$ maka akan meningkatkan tingkat triple bottom line $20,1 \%$ dengan asumsi variabel independen lainnya tetap.

10. Nilai koofisien regresi variabel ukuran dewan komisaris $\left(b_{9}\right)$ bernilai positif yaitu sebesar 0,060, maka dapat diartikan bahwa setiap peningkatan ukuran dewan komisaris sebesar $1 \%$ maka akan meningkatkan tingkat triple bottom line sebesar $6 \%$ dengan asumsi variabel independen lainnya tetap.

11. Nilai koofisien regresi variabel ukuran komite audit $\left(b_{10}\right)$ bernilai negatif yaitu sebesar -0,231, maka dapat diartikan bahwa setiap penurunan ukuran komite audit sebesar $1 \%$ maka akan meningkatkan tingkat triple bottom line sebesar $23,1 \%$ dengan asumsi variabel independen lainnya tetap.

\section{Pembahasan}

Pengaruh variabel leverage terhadap Tingkat Triple bottom line

Dari tabel coeffisien diperoleh nilai signifikansi $0,055>0,05$ maka $\mathrm{H}_{1}$ ditolak artinya leverage tidak berpengaruh signifikan terhadap pengungkapan triple bottom line.

Tidak berpengaruhnya leverage terhadap pengungkapan triple bottom line dalam penelitian ini dikarenakan suatu kondisi yang mengindikasikan bahwa perusahaan yang mempunyai leverage yang tinggi beresiko memiliki biaya monitoring yang tinggi pula. Sehingga manajemen secara konsisten lebih penting mengungkapkan untuk tujuan monitoring agar memastikan kepada kreditor kemampuan untuk membayar utang dari pada mengungkapkan Triple Bottom Line. Hal ini dilakukan untuk mengurangi biaya agensi.

\footnotetext{
Pengaruh variabel profitabilitas terhadap tingkat pengungkapan triple bottom line

Dari tabel coeffisien diperoleh nilai signifikansi $0,095>0,05$ maka $\mathrm{H}_{2}$ ditolak Artinya profitabilias tidak berpengaruh signifikan terhadap pengungkapan triple bottom line.

Tidak berpengaruhnya profitabilitas terhadap pengungkapan Triple Bottom Line dikarenakan rata-rata profitabilitas dalam penelitian ini relatif kecil yaitu 20,5 persen sehingga kurang menjelaskan pengungkapan triple bottom line. Secara teori tingkat profitabilitas bertujuan untuk
}

mengukur kemampuan perusahaan untuk memperoleh keuntungan atau profitabilitas pada tingkat penjualan, aset dan modal saham tertentu. Oleh karena itu, jika perusahaan mengalami keuntungan yang tinggi, perusahaan tersebut tidak akan mengungkapkan informasi yang lebih lengkap dalam pelaporan keuangannya, (Nugroho dan Purwanto,2013).

Pengaruh variabel likuiditas terhadap Tingkat pengungkapan triple bottom line

Dari tabel coeffisien diperoleh nilai signifikansi $0,009<0,05$ maka $\mathrm{H}_{3}$ diterima Artinya likuiditas berpengaruh signifikan terhadap pengungkapan triple bottom line.

Hasil penelitian menemukan bahwa likuiditas memiliki pengaruh yang signifikan terhadap pengungkapan Triple bottom line dikarenakan likuiditas merupakan salah satu faktor penting bagi pengungkapan yang dilakukan oleh perusahaan, karena investor, kreditor dan pemangku kepentingan lainnya sangat memperhatikan status going concern perusahaan. Sesuai dengan teori agensi dalam hubungannya manajer sebagai agen berusaha untuk memenuhi kepentingan investor (prinsipal) dengan meningkatkan nilai perusahaan dan menjaga kelangsungan operasi perusahaan dengan menjaga likuiditasnya agar perusahaan dapat bertahan dengan lama. Jika suatu perusahaan sangat likuid kemungkinan besar perusahaan tersebut memberikan rincian lebih lengkap terhadap pengungkapan triple bottom line guna untuk kelangsungan hidup perusahaannya.

Pengaruh variabel jenis industri terhadap tingkat pengungkapan triple bottom line.

Dari tabel coeffisien diperoleh nilai signifikansi $0,019<0,05$ maka $\mathrm{H}_{4}$ diterima Artinya jenis industri berpengaruh signifikan terhadap pengungkapan triple bottom line.

Berpengaruhnya variabel jenis industri dalam penelitian ini karena dapat diindikasikan perusahaan high profile lebih mengungkapkan triple bottom line dari pada perusahaan low profile.

Pengaruh variabel umur perusahaan terhadap tingkat Pengungkapan triple bottom line.

Dari tabel coeffisien diperoleh signifikansi 0,001 <

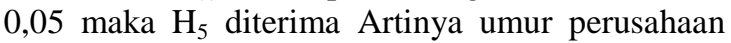
berpengaruh signifikan terhadap pengungkapan triple bottom line.

Berdasarkan hasil pengujian pengaruh variabel umur perusahaan terhadap luas pengungkapan Triple Bottom Line, dapat diketahui bahwa variabel umur perusahaan berpengaruh terhadap pengungkapan Triple Bottom Line. Semakin lama perusahaan berdiri, semakin banyak perusahaan belajar dan selalu mencoba untuk beradaptasi dengan kebutuhan yang ada untuk mendukung citra 
dan legitimasi sebuah perusahaan dimata publik sesuai dengan teori legitimasi.

Pengaruh variabel kepemilikan asing terhadap tingkat Pengungkapan triple bottom line.

Dari tabel coeffisien diperoleh nilai signifikansi 0,693 > 0,05 maka $\mathrm{H}_{6}$ ditolak artinya kepemilikan asing tidak berpengaruh signifikan terhadap pengungkapan triple bottom line.

Hasil penelitian ini menemukan bahwa kepemilikan asing tidak memiliki pengaruh yang signifikan terhadap pengungkapan TBL. Hal ini menunjukkan bahwa pihak asing pada perusahaan di Indonesia masih menganggap bahwa laporan tanggung jawab sosial sebagai laporan yang bersifat sukarela (voluntary) sehingga tidak perlu diungkapkan (Mahatma, 2010).

Pengaruh variabel kepemilikan institusi terhadap tingkat Pengungkapan triple bottom line.

Dari tabel coeffisien diperoleh signifikansi 0,689 > 0,05 maka $\mathrm{H}_{7}$ ditolak Artinya kepemilikan institusi tidak berpengaruh signifkan terhadap pengungkapan triple bottom line.

Kepemilikan institusional merupakan kepemilikan perusahaan yang sahamnya dimiliki oleh institusi. Peran investor institusional dalam melakukan pengawasan terhadap kinerja perusahaan, mencegah terjadinya konflik kepentingan dari pemegang saham minoritas perusahaan. Semakin besar kepemilikan oleh institusional maka akan semakin besar peran kepemilikan institusional tersebut dalam perusahaan sehingga aspek pengawasan terhadap keterbukaan informasi akan semakin meningkat.

Pengaruh variabel kepemilikan manajemen terhadap tingkat Pengungkapan triple bottom line.

Dari tabel coeffisien diperoleh nilai signifikansi 0,115>0,05 maka $\mathrm{H}_{8}$ ditolak artinya kepemilikan manajemen tidak berpengaruh signifikan terhadap pengungkapan triple bottom line.

Tidak berpengaruhnya variabel kepemilikan manajemen dalam penelitian ini karena jumlah kepemilikan manajerial dalam penelitian ini cukup kecil. Konflik kepentingan antara manajer dengan pemilik menjadi semakin besar ketika kepemilikan manajer terhadap perusahaan semakin kecil.

Pengaruh variabel ukuran dewan komisaris terhadap tingkat Pengungkapan triple bottom line.

Dari tabel coeffisien diperoleh nilai signifikansi 0,670 > 0,05 maka $\mathrm{H}_{9}$ ditolak artinya ukuran dewan komisaris tidak berpengaruh signifikan terhadap pengungkapan triple bottom line.
Tidak berpengaruhnya variabel ukuran dewan komisaris dikarenakan besar kecilnya ukuran dewan komisaris tidak memengaruhi pengungkapan triple bottom line, ini berarti bahwa besar kecilnya ukuran dewan komisaris tidak dapat menjamin adanya mekanisme pengawasan yang lebih baik dan pengungkapan tanggung jawab sosial yang lebih baik.

Pengaruh variabel ukuran komite audit terhadap tingkat Pengungkapan triple bottom line.

Dari tabel coeffisien diperoleh nilai signifikansi 0,096 > 0,05 maka $\mathrm{H}_{10}$ ditolak artinya ukuran komite audit tidak berpengaruh signifikan terhadap pengungkapan triple bottom line.

\section{KESIMPULAN DAN SARAN}

Kesimpulan

1. Variabel leverage tidak berpengaruh signifikan terhadap tingkat pengungkapan triple bottom line pada perusahaan LQ45 tahun 2014-2016.

2. Variabel Profitabilitas tidak berpengaruh signifikan terhadap tingkat pengungkapan triple bottom line pada perusahaan LQ45 tahun 2014-2016.

3. Variabel likuiditas berpengaruh signifikan terhadap tingkat pengungkapan triple bottom line pada perusahaan LQ45 tahun 2014-2016.

4. Variabel jenis industri berpengaruh signifikan terhadap tingkat pengungkapan triple bottom line pada perusahaan LQ45 tahun 2014-2016.

5. Variabel umur perusahaan berpengaruh signifikan terhadap tingkat pengungkapan triple bottom line pada perusahaan LQ45 tahun 2014-2016.

6. Variabel kepemilikan asing tidak berpengaruh signifikan terhadap tingkat pengungkapan triple bottom line pada perusahaan LQ45 tahun 2014-2016.

7. Variabel kepemilikan institusi tidak berpengaruh signifikan terhadap tingkat pengungkapan triple bottom line pada perusahaan LQ45 tahun 2014-2016.

8. Variabel kepemilikan manajemen tidak berpengaruh signifikan terhadap tingkat pengungkapan triple bottom line pada perusahaan LQ45 tahun 2014-2016.

9. Variabel ukuran dewan komisaris tidak berpengaruh signifikan terhadap tingkat pengungkapan triple bottom line pada perusahaan LQ45 tahun 2014-2016.

10. Variabel ukuran komite audit tidak berpengaruh signifikan terhadap tingkat pengungkapan triple bottom line pada perusahaan LQ45 tahun 2014-2016. 


\section{Saran}

Melihat kesimpulan sebelumnya terdapat beberapa saran dan pertimbangan yang disajikan dalam penelitian ini antara lain:

1. Periode penelitian selanjutnya sebaiknya lebih dari 3 tahun karena periode yang lebih panjang diharapkan dapat memungkinkan tingkat generalisasi sehingga mencerminkan kondisi perusahaan yang sebenarnya.

2. Untuk peneliti selanjutnya dapat menggunakan data perusahaan yang terdaftar di BEI tidak hanya terbatas pada yang LQ45. Peneliti selanjutnya juga dapat menggunakan data perusahaan yang terdaftar pada sektor-sektor industri yang terdaftar di BEI atau dapat menggunakan data perusahaan yang terdaftar pada ISSI atau JII atau pada perusahaan syariah di Indonesia.

3. Untuk peneliti selanjutnya sebaiknya menggunakan variabel kinerja keuangan agar memperoleh hasil yang lebih baik lagi.

\section{DAFTAR PUSTAKA}

Ale, Lusyana. 2014. Pengaruh Ukuran Perusahaan, Leverage, Kepemilikan Institusional Terhadap Pengungkapan Corporate Social Responbility. Jurnal Ekonomi Akuntansi, P1-19. Universitas Atma Jaya Yogyakarta.

Anggraini, F. R. R. 2006. "Pengungkapan Informasi Sosial dan Faktor-Faktor yang Mempengaruhi Pengungkapan Informasi Sosial dalam LaporaN Keuangan Tahunan". Simposium Nasional Akuntansi IX Padang, Vol. 9

Aulia, Sandra. TB MH Idris Kartawijaya. 2011. Analisis Pengungkapan Triple Bottom Line danFaktor Yang Mempengaruhi; Lintas Negara Indonesia dan Jepang. Simposisum nasionalAkuntansi XIV. Aceh

Bursa Efek Indonesia, Laporan Tahunan www.idx.co.id, diakses 26 Oktober 2015 Ghozali, I. 2005. Aplikasi Analisis Multivariate Dengan Program SPSS. Semarang: Badan Penerbit Universitas Diponegoro.

Djuitaningsih, Tita. 2012. Pengaruh Manajemen Laba dan Mekanisme Corporate Governance terhadap Corporate Social Responsibility Disclosure. Media Riset Akuntansi, Vol. 2 No. 2 Agustus 2012.

Elkington, John. 1997. Cannibals with Forks: The Triple Bottom Line of 21st Century Business.Capston. Oxford.
Fauzi, hasan, Goran Svensson and Azhar Abdul Rahman. 2010.Triple Bottom Line as Sustainable Corporate Performance: A Proposition for the Future. Sustainability Journal.

Febrina dan Suaryana. Agung IGN. 2011. FaktorFaktor yang Mempengaruhi Kebijakan Pengungkapan Tanggungjawab Sosial dan Lingkungan pada Perusahaan Manufaktur di Bursa Efek Indonesia. Simposium Nasional Akuntansi 1, Fakultas Ekonomi Universitas Syiah Kuala, Banda Aceh, 21-22Juli.

Febrianti, Meiriska. 2012. Faktor-Faktor yang Mempengaruhi Nilai Perusahaan Pada Industri Pertambangan di Bursa Efek Indonesia. Jurnal Bisnis dan Akuntansi.Vol. 14, No. 2, Agustus 2012, Hlm. 141-156

Ghozali, I. dan A. Chariri. 2007. Teori Akuntansi. Semarang: Badan Penerbit Universitas Diponegoro.

Ghozali, Imam, 2009. Aplikasi Analisis

Multivariate Dengan Program SPSS, Edisi Keempat, Badan Penerbit Universitas Diponegoro: Semarang.

Hackston, David and Markus J. Milne. 1996. "Some determinants of social and environmental disclosures in New Zealand companies". Accounting, Auditing \& Accountability Journal. Vol. 9, No. 1, pp. 77-108.

Hendrison, 2001:206. Tentang Teori CSR.Diakses https://djoe2x.wordpress.com/2010/01/2/5/te ntang-teori-csr/.pada tanggal 24 april 2018

https://wisuda.unud.ac.id/pdf/1315351146-2bab\%201.pdf . diakses pada tanggal 28 maret 2018

https://www.scribd.com/doc/299471861/Faktorfaktor-yang-mempengaruhi-TripleBottom-Line-di-Indonesia

Jennifer Ho, L., C., dan Taylor, M. E. 2007. An Empirical Analysis of Triple Bottom Line Reporting and its Determinants: Evidence from the United States and Japan. Journal of International Financial Management and Accounting Vol. 18 No. 2, pp $123-150$.

Machmud, Novita Dan Djakman, Chaerul. 2008. Pengaruh Struktur Kepemilikan Terhadap Luas Pengungkapan 
Volume 7, Nomor 1, Februari 2019

Tanggung Jawab Sosial (CSR

Disclosure) Pada Laporan Tahunan

Perusahaan; Studi Empiris Pada

PerusahaanPublik Yang Tercatat Di

Bursa Efek Indonesia Tahun 2006.

Simposium Nasional Akuntansi XI.

Kartika, Andi. 2009. Faktor-faktor yang

Mempengaruhi Audit Delay di Indonesia

(Studi kasus pada perusahaanperusahaan LQ 45 yang terdaftar di Bursa Efek Jakarta). Jurnal Bisnis dan Ekonomi (JBE) . Maret Tahun 2009. Hlm 117.

Mahatma, Angling. 2010. Pengaruh Karakteristik Perusahaan dan Regulasi Pemerintah Terhadap Pengungkapan Corporate Social Responsibility (CSR) pada Laporan Tahunan di Indonesia. Skripsi. Fakultas Ekonomi Universitas Diponegoro.

Marwata. 2001. Hubungan Karakteristik Perusahaan dan Kualitas Ungkapan Sukarela Dalam Laporan Tahunan Perusahaan Publik di Indonesia. Tesis. Universitas Gajahmada.

Nofandrilla. 2008. Analisis Pengaruh Karakteristik Perusahaan terhadap Kebijakan Pengungkapan Tanggung Jawab Sosial (Studi Empiris pada Perusahaan Pertambangan yang Terdaftar di Bursa Efek Jakarta. Jurnal tidak dipublikasikan. Surakarta: FE UNS. 
